\begin{tabular}{|c|c|c|}
\hline$\sqrt[N]{ }$ & 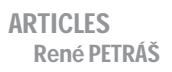 & 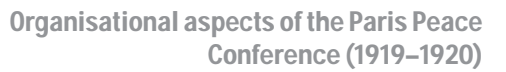 \\
\hline
\end{tabular}

\title{
Organisational aspects of the Paris Peace Conference (1919-1920)
}

\section{René PETRÁŠ}

\author{
Ústav právních dějin, Právnická fakulta, Univerzita Karlova v Praze \\ Institute of Legal History, Faculty of Law, Charles University in Prague \\ Nám. Curieových 901/7, 11640 Praha1, Czech Republic \\ petras@prf.cuni.cz
}

The Paris Peace Conference (1919-1920) was expected to resolve all the contemporary issues, which were extremely numerous. World War I had been (with the exception of World War II) the most brutal war in human history. Moreover, it broke out after a very long period of relative peace, and society was not prepared for a war. World War I was terminated by a series of separate armistices with the defeated Central Powers. The first state was Bulgaria (at the end of September 1918), followed by Turkey, Austria-Hungary, and finally Germany. The rapid end of the war surprised the Allied victors in many ways, as the fighting had been expected to move to Germany in 1919. However, the German imperial regime swiftly collapsed at the beginning of November, and the new political leaders desired peace. At any rate, towards the end of 1918, the situation was rather chaotic in many parts of Europe, characterised by a hasty creation of new states in the large area between Germany, Italy, and Russia, as well as by revolutionary conditions in many regions.

The former tsarist Russia was in a state of complete disorder and confusion, with severe fighting involving the Bolsheviks, their opponents of various political inclinations, as well as nationalists seeking separation from the hated country. Although Russia was originally a key member of the Allied victors, it was not invited to the peace conference. That was not principally due to the March 1918 peace agreement between the Bolsheviks and Germany, enabling the Germans to undertake the last major offensive in France, but rather by the total chaos in Eastern Europe that the diplomats in Paris found difficult to tackle. ${ }^{1}$

However, as this paper cannot provide an in-depth account, it will focus mainly on the organisational aspects of the peace conference. The conference was held in Paris, recognising the important position of the principal and severely affected country of the Allied victors. Preliminary conference meetings started on 12 January 1919, and the conference was officially opened on 18 January in the Palace of Versailles. The date was symbolic, commemorating the $48^{\text {th }}$ anniversary of unified Germany, which had been officially declared in occupied France. The Allied victors officially aimed to subdue the German aggression that had been intensifying after the German unification. While such exaggerated symbolism may appear surprising nowadays, it was quite typical of its time. Another characteristic feature of the peace conference was the fact that only one head of state participated in it. Hence, individual countries were represented by prime ministers, ministers of foreign affairs or merely by diplomats, and, with the exception of the US, sovereigns or presidents were not present. For a certain period of time, it appeared likely that President

1 MACMILLAN, Margaret: Mírotvorci: Pařǐžská konference 1919, Praha 2004, 78-82. 
T. G. Masaryk might come to Paris, but eventually the principle that the conference should be attended by just one head of state was observed. ${ }^{2}$

The US President Woodrow Wilson represented one of the three major Allied victors and, moreover, symbolised the new world and new diplomacy. The US had entered the war relatively late, officially proclaiming very idealistic aims. Furthermore, during the war, President Wilson prepared Fourteen Points (8 January 1918), a blueprint for world peace. The first point directly concerned the peace conference, calling for public negotiation of treaties and elimination of secret diplomacy, which had already been requested by the Bolsheviks. Thus, backstage negotiations, which had been very common in the past, were rejected and were slated to be replaced with open negotiations. Nevertheless, the reality was quite different, even during the Paris Peace Conference itself. Strategically, the most significant was the fourteenth point, promising to form a general association of nations to guarantee political independence and territorial integrity. This idea of the very first international organisation was one of the key problems of the conference. President Wilson's Fourteen Points were not a mere formal proclamation, but were officially considered as the basis for peace, endorsed even by the defeated countries that were asking for armistice. ${ }^{3}$

The meeting was opened by French President Raymond Poincaré, who, as mentioned above, did not participate in the conference after his opening speech, leaving President Wilson as the only head of state at the conference. The opening speech suggested a characteristic, and truly controversial, aspect of the conference, namely a clear distinction between the winners and the defeated states. In particular, the unequivocal statement that the defeated states, especially Germany, were the only blameworthy parties in the war was dubious. Paradoxically, that attitude was nourished by the openness of the new governments in Germany and Austria, which readily published relevant documents, while the victorious allied states provided no access to the archives whatsoever.

Scarce sources of inspiration were available, because a peace conference of this scale was unprecedented. Yet, there was the model of the Vienna Congress (1814-1815), which put an end to long wars with revolutionary and later Napoleonic, France. However, the tone of negotiations at the Vienna Congress was friendly, disregarding the differences between the winners and losers, quite unlike Paris in 1919. That may have contributed to the long-lasting peace after 1815. Moreover, Vienna had not been much affected by the war, as the last fighting there took place in 1809 and was limited in scale. By contrast, Paris had been subject to severe bombing by Germany only a few months before the peace conference. Therefore, it may have been better to choose a city less affected by the war in $1919 .{ }^{4}$

From its start in January 1919, the Paris Peace Conference became a milestone in the development of diplomacy as far as languages are concerned. Over the previous centuries, French had been the language of diplomacy, but from the beginning of the conference, English was put on equal footing. That may have been due to the fact that out of the three Allied victors, two countries were English-speaking. In addition, the language skills of the leaders played a role too; while neither Woodrow Wilson nor the British Prime Minister

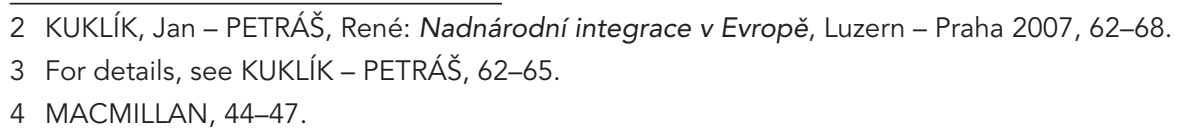




\begin{tabular}{|c|c|c|}
\hline$\sqrt{x}$ & 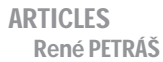 & 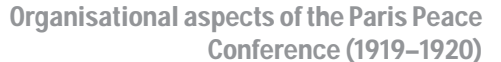 \\
\hline
\end{tabular}

David Lloyd George could speak French, the French prime minister Georges Clemenceau spoke English fluently thanks to his American wife, and the Italian prime minister Vittorio Orlando spoke English as well.

Twenty-seven victorious Entente states and five British dominions took part in the conference, while the defeated states were only to be formally invited to accept the peace conditions. Hence, there was a clear distinction between the winners and losers, although the winners did not have an equal position either. That was logical, because individual countries engaged in the war in very different ways. Great powers mobilised millions of soldiers (e.g., the UK 9 million, France over 8 million, the US 4 million) out of whom hundreds of thousands died (and in one case, over a million: France 1.4 million, the UK 0.9 million, the US "only" 126 thousand). Smaller countries had fewer casualties, such as Belgium with 14 thousand soldiers or Portugal with 7 thousand soldiers. ${ }^{5}$

On the other hand, many small states were much more damaged by the war than most great powers. While Russia and the northeast of France were severely hit, the British or US territories were hardly affected at all. Belgium, Romania, and Serbia were completely ravaged. Many states, however, formed part of the Allied victors only formally; for example, the Latin American countries (e.g., Brazil) only sent a handful of paramedics and pilots. Similarly, Japan entered the war shortly after it broke out, but apart from the occupation of the German colonies in the Pacific region, its contribution to war efforts was limited, as evidenced by the estimated number of 300 soldiers killed.

The different levels of engagement in the war should have been taken into account at the peace conference, but the results were rather dubious. As Macmillan describes, "Portugal, which contributed 60,000 soldiers at the Western Front, considered it a slap in the face that they should only have one official delegate, while Brazil, which provided only a paramedic unit and a few pilots, should have three delegates." ${ }^{6}$ The great powers became involved in these disputes too. In this particular case, the UK supported its traditional Portuguese ally, while the US, in line with the idea of pan-Americanism, stood up for Brazil. It is noteworthy that Brazil was very self-confident and desired a permanent seat at the newly established League of Nations Council, and thus to be recognised as a great power. However, those megalomaniac requirements were exaggerated, not reflecting Brazil's actual involvement in the war or its (at that time) rather limited demographic and economic power. Brazil's requirements were not met in the League of Nations and the country (as the first state ever) withdrew from the organisation in 1926. The dispute, which certainly did not help to improve international relations because it cast doubt on the role of the League of Nations as the key element of the peace system, was rooted in the Paris Peace Conference. ${ }^{7}$

Thus, the unequal position of individual states during negotiations was a very problematic issue of the conference. As mentioned above, the defeated countries were excluded, which remains a topic for discussion even today. Equally controversial is the fact that even the neutral states were not invited, although the peace conference dealt not only with problems directly relevant to the ending war, but also with general issues such as the

5 According to Encyclopaedia Americana, 1966 and Encyclopaedia Britannica, 1966 - cited in: KLIMEK, Antonín: Jak se dělal mír roku 1919. Československo na konferenci ve Versailles, Praha 1989 (Slovo k historii no. 19), 16.

6 MACMILLAN, 73.

7 KUKLÍK - PETRÁŠ, 77-81. 
establishment of the League of Nations. It is true, though, that there were few neutral states during the war, and those generally small states (such as Switzerland or Latin American countries) were reluctant to become involved in global issues. However, the greatest controversy was the unequal position of victorious states. The UK eventually proposed a compromise, suggesting that beside plenary sessions smaller meetings dominated by the great powers should be held for the sake of a greater speed in negotiations.

In this way, the conference came to be monopolised by five great powers, in particular by the UK, the US, and France, and three key persons: Woodrow Wilson, David Lloyd George, and Georges Clemenceau. There were only seven plenary sessions, which did not provide an opportunity for genuine discussions and arguments. A noticeable exception was the resistance of Central European and Balkan new states and states whose territory had been enlarged to accept commitments regarding the protection of minorities. That resistance was widely noticed at the conference as one of the largest open disputes. During negotiations, the great powers' representatives often treated smaller states with arrogance, which was so apparent in the professorial manners of Woodrow Wilson. Georges Clemenceau behaved in a similar way, particularly when the interests of France were at stake. ${ }^{8}$

The major great powers had a key role at the conference, making up the so-called Council of Ten, which consisted of the delegations' presidents and prime ministers. Hence, the US was represented by Woodrow Wilson and Robert Lansing, the UK by David Lloyd George and Arthur James Balfour, France by Georges Clemenceau and Stéphen Pichon, Italy by Vittorio Orlando and Sidney Sonnino, and Japan by Nobuaki Makino and Sutemi Chinda. Very often, however, only the delegations' leaders or their deputies participated in the negotiations, creating thus the Council of Five, and Japan was frequently excluded, leading to the Council of Four, and sometimes Italy did not participate, which resulted in the Council of Three. The Japanese had the weakest position because the composition of their delegation was not as prestigious as was the case in other delegations; in addition, the language skills of the delegates were insufficient, which caused some practical problems. Italy was at a disadvantage due to failures of its war operations; at the end of 1917, Italy would not have managed without the assistance of other great powers. On the other hand, the country raised considerable demands. The Italian delegation often pursued its demands tactlessly, culminating in its early departure from the conference. When that did not result in a deadlock of negotiations as they had expected, the Italians quietly returned. ${ }^{9}$

The peace conference was expected to undertake an enormous number of tasks, but the organisation of this gigantic event was rather insufficient. This was partly due to the attitude of many key persons, in particular Woodrow Wilson and George Clemenceau. The US President Woodrow Wilson fervently advocated the establishment of the League of Nations, which only met with indifference or even resistance on the part of the other states, and sometimes on the part of the members of his own delegation too. It was a radical step in international law, creating the very first truly international organisation and potentially a new world system, which made some experienced diplomats raise their eyebrows. ${ }^{10} \mathrm{Re}-$

8 MACMILLAN, 275-280.

9 KLIMEK, 16.

10 For details, see KUKLÍK - PETRÁŠ, 62-65. 


\begin{tabular}{|c|c|c|}
\hline$\sqrt{x}$ & 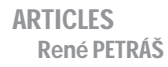 & 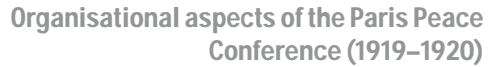 \\
\hline
\end{tabular}

grettably, Wilson's stubborn promotion of the organisation seriously complicated the negotiations, but he undoubtedly realised that such radical progress in international law was only possible in the exceptional circumstances at that time.

George Clemenceau, no doubt, also strongly contributed to the chaotic situation at the conference; he was ridiculed for being a worthless negotiator and for lacking control over his own behaviour. His habit of sitting in the president's chair with closed eyes, appearing sound asleep, which made him look like an infirm old man approaching eighty years of age, was perceived rather negatively. He only showed some activity when the interests of France were involved, and then, his behaviour became aggressive and choleric. The secretary of the conference could have been a powerful person, but Clemenceau unfortunately had his way in appointing the rather feeble M. Dutasta. As Klimek explains, "There were rumours that the French prime minister had chosen Dutasta for the composure with which he let the choleric "tiger" (as was Clemenceau's nickname) insult him." ${ }^{11}$

The negotiations often proceeded very hastily, as illustrated by an example from Czechoslovakia, when a prominent lawyer, Václav Joachim, at the end of 1919, sought to obtain reports from the peace conference in order to explore the motivation behind certain provisions of the so-called minor Treaty of Saint-Germain-en-Laye with Czechoslovakia: "Professor Krčmár confirmed that no reports or preparatory acts existed in relation to the treaty with our country, because our delegates had been presented with the complete text of the treaty. Consequently, that source of interpretation could not be relied on." ${ }^{12}$ However, in international law, treaties are interpreted also by looking at preparatory acts and circumstances surrounding the conclusion of the treaties, and such sources are considered as ancillary interpretative means. As a result, the conference was rather chaotic.

The author of this paper has studied the peace conference thoroughly, particularly as regards the newly established protection of minorities under international law, which was imposed on the states between Germany, Italy, and Russia, one of them being Czechoslovakia. ${ }^{13}$ This issue will now be discussed to illustrate a number of problems. It is absurd that certain details captivated the attention of the great powers, such as Athos, the "monastic state", while other crucial disputes concerning German and Hungarian minorities were underestimated, even though they could have been anticipated at the conference.

The process of establishing a system of minority protection under international law was in many ways quite curious. Various Jewish organisations, in particular from the US, played a key part. While individual groups of nationalists mainly sought to obtain land for their states and they perceived the protection of minorities as burdensome, the Jews had no state of their own and they concerted their effort to obtain international guarantees safeguarding their position. They secured the implementation of international protection through President Wilson, whose democratic party featured a strong Jewish lobby. Moreover, the Ku

11 For an ironic, but apt description, see KLIMEK, 15.

12 Archiv Ministerstva zahraničních věcí (Archives of the Ministry of Foreign Affairs, Praha; hereinafter referred only as AMZV), fond Mírová konference v Paříži a reparace 1918-1938 (Paris Peace Conference and Reparations 1918-1938), kart. 55, file no. Cb III 1, "Minoritní smlouva s čsl. rep.", dopis dr. Joachima z Prahy (23 December 1919).

13 See, for example, PETRÁŠ, René: Mezinárodní ochrana menšin v teorii a praxi meziválečné Evropy, in: Zrod nové Evropy. Versailles, St.-Germain, Trianon a dotváření poválečného mírového systému, Praha 2011, 415-424. 
Klux Klan was very powerful at that time, and the Klan's members were bothered by the Jews coming from Romania, where they had faced severe oppression. Hence, a number of important elements of the peace system originated in a rather curious way and were, from the very beginning, susceptible to potential future problems. ${ }^{14}$

The negotiations concerning minorities often blatantly illustrated immense inequalities between formally equal states as well as mistrust by many politicians of new arrangements and, in particular, of successor states. There was a concern that Europe could descend into total chaos, as Jan Smuts, a South African statesman, strongly emphasised in his plan. He requested that all states established in the territory of Austria-Hungary and Turkey be placed under international supervision. Although the plan was never implemented in respect to Central Europe, it was used, in a modified form, for former Turkish and colonial territories as the so-called mandates. ${ }^{15}$

In the light of these radical plans to substantially restrict the sovereignty of Central European states, it is hardly surprising that it was decided to pursue the idea of international protection of minorities that interfered in the domestic affairs of relevant countries. ${ }^{16}$ Initially, there was an attempt to address minority issues in general terms directly in the covenant of the League of Nations. It was planned to include an article enabling territorial modifications based on the self-determination of nations, but such a provision was strongly opposed and was eventually left out. Because of the borders that did not reflect the distribution of minorities, a provision ensuring the protection of minorities was to be included. ${ }^{17}$ The first proposals of the League of Nations covenant contained no provisions on minorities, and only the so-called second Wilson plan included an article dealing with the protection of minorities. Only new states were to be bound by the article, and they would have to guarantee to all members of minorities total equality with other citizens. The League of Nations was to supervise how these commitments were fulfilled. The proposal was not adopted, mainly because the British opposed it. ${ }^{18}$ Hence, it was necessary to find a compromise between the British and American positions, which, however, did not centre merely on the issue of minorities. The compromise proposal authored by David Miller and Cecil Hurst did not mention national minorities at all, and the article on religious equality was considerably modified.

That compromise was supposed to be addressed at the meeting of the commission for the League of Nations from 3 February to 13 February 1919. However, the result of the meeting was strongly influenced by the demands of the Japanese delegation. The delegation wished to incorporate into the covenant a provision ensuring that the citizens of the League of Nations member states are treated in the territory of other member states

14 For details, see PETRÁŠ, René: Menšiny v meziválečném Československu, Praha 2009, 27-45.

15 HUDSON, Mauley O.: The Protection of Minorities and Natives in Transferred Territories, in: What Really Happened at Paris. The Story of the Peace Conference 1918-1919 by American Delegates, HOUSE, Edward M. - SEYMOUR, Charles (eds.), New York 1921, 224 et seq.

16 PEŠKA, Zdeněk: Otázka národnostních menšin na Pařǐžské mírové konferenci, in: Zahraniční politika, vol. 9, $1930,218-219$

17 For details, see PETRÁŠ, 2009, 32-34.

18 HUDSON, 210; GÜTERMANN, Christoph: Das Minderheitenschutzverfahren des Völkerbundes, Berlin 1979, 17-19. 
the same as the citizens of that state. The proposal was never adopted, though, as it was strongly opposed by both the UK and the US. In addition, the article on religious equality was subsequently removed from the covenant, because the Japanese delegation pursued its demands jointly with this article, and the commission, in order to steer clear of all those controversial issues, decided to remove the article on religious equality as well. Thus, this issue shows how the interests of individual countries came to the forefront, as illustrated by the problem of Japanese immigrants in British and US territories and the sensitive issue of racial equality, which was advocated by the Japanese but rejected by western countries. Indeed, the negotiations about the protection of minorities to be included in the League of Nations covenant (which was adopted at the plenary session on 28 April 1919) absolutely failed, leaving the minority issues unresolved. ${ }^{19}$

Although the efforts to include the protection of minorities in the League of Nations covenant failed, the advocates of minority protection persevered. They were mainly the members of the US delegation. After the failed attempt to incorporate the protection of minorities into the covenant, they tried to ensure that the relevant provisions were incorporated directly into the peace treaties. Poland was the first country to have minority protection included in the peace treaty with Germany, and if the measure was deemed successful, other countries, such as Czechoslovakia or Romania, were to follow. ${ }^{20}$ On 1 May, the issue was discussed by the Highest Council of the conference and Woodrow Wilson in particular emphasised the necessity to incorporate into the treaty with Germany provisions about the protection of Jews and Germans in Poland. The meeting resolved to entrust a special new commission with the task of drawing up a relevant proposal. The new commission was officially referred to as the "Commission for New States", but was commonly called the Minorities Commission, and its task was to negotiate international commitments (primarily) for Poland and other states. ${ }^{21}$ It is noteworthy that commitments under international law regarding protection of minorities were imposed on most defeated countries as well, but those countries posed no problems as the peace treaties were largely imposed on them. However, the great powers had to negotiate these provisions with their own allies - Poland, Czechoslovakia, Romania, the Kingdom of Serbs, Croats and Slovenes, and Greece. ${ }^{22}$

The Commission for New States was established on 1 May 1919, comprising only five great powers: France (Philippe Berthelot), the UK (James Headlam-Morley), the US (Manley O. Hudson and David Miller), and later also Italy (from 13 May) and Japan (from 29 May). ${ }^{23}$ The leaders of the peace conference, Wilson, Clémenceau, and Lloyd George, assigned to the commission the task to draw up proposals for treaties dealing with the protection of minorities. At first, only the treaties with such new states as Poland and Czechoslovakia

19 TEMPERLEY, Harold W. V. (ed.): A History of the Peace Conference of Paris, vol. V, London 1921, 123; PEŠKA, 218-222.

20 MILLER, David Hunter: My Diary at the Conference of Peace, vol. XIII, New York 1924, 15.

21 For details, see PETRÁŠ, René: Meziválečné Polsko, Československo a mezinárodněprávní ochrana menšin, in: Świat, Europa, Mała ojczyzna. Studia ofiarowane Profesorowi Stanisławowi Grodziskiemu w 80-lecie urodzin, Biełsko-Biała 2009, 853-860.

22 For details on documents for the negotiations see, for example, AMZV, f. Pařížský archiv (Paris archive), kart. 50, doc. no. 5002.

23 MILLER; GÜTERMANN, 20; TEMPERLEY, 123 et seq.; HUDSON, 211. 
were envisaged, but on 7 May the Highest Council decided that protection of minorities would equally apply to Serbia (the Kingdom of Serbs, Croats, and Slovenes), Romania, and Greece because their territory would expand significantly. A major issue that needed to be addressed was Polish citizenship and political and religious equality. ${ }^{24}$ By 14 May, the commission had finalised its first task - a treaty with Poland - and submitted it to the Highest Council and the Polish delegation. This proposal differed, to a certain extent, from the later text of the treaty. The states that were supposed to enter into treaties were reluctant to do so; in particular, Romania threatened not to sign the peace treaty at all. France was willing to reduce the requirements for the protection of minorities in Romania and elsewhere, pursuing its political interests, but the other great powers rejected all concessions. ${ }^{25}$

After vigorous debates, the commission decided to present the issue to the plenary session of the peace conference on 31 May 1919, where the countries that were forced to accept the commitments regarding the protection of minorities vociferously expressed their disapproval. During the meeting, the representatives of those states vehemently protested against the envisaged system for protection of minorities. It was one of the few open and public disputes at the conference, widely perceived as an act of rebellion by small states. ${ }^{26}$ The Czechoslovak delegation's approach, as promoted by Edvard Beneš, was more diplomatic. It utilised (mainly Czech) experts who had prepared many relevant documents of superior quality for the delegation. ${ }^{27}$ Edvard Beneš realised that Czechoslovakia, and in particular its legislation, would have no difficulty meeting the obligations under minority treaties. ${ }^{28}$

From among the great powers, France was against the treaties incorporating the protection of minorities, because it perceived such protection as interference in the domestic affairs of the states. It argued that the relevant countries would, in their own interest, sufficiently accommodate the needs of their minorities. Nevertheless, the other great powers eventually had their way in approving the treaties, as the US (being the most active of all), the UK, and the Italian delegation showed their support. The small states, including Czechoslovakia, thus had to accept the imposed protection of minorities. After negotiations on $31 \mathrm{May}$, it was clear that the designated countries were obliged to accept the minority treaties and the Commission for New States only discussed individual provisions. The delegations of Czechoslovakia and Greece preferred to participate - essentially unofficially - in the preparatory work, rather than letting others negotiate in their absence. Consequently, the results were better than in the case of the Kingdom of Serbs, Croats, and Slovenes, Poland, and Romania, whose delegations absolutely refused to cooperate with the commission in the drafting process. In particular, Edvard Beneš participated very actively during the negoti-

24 The treaty provisions had to be complemented by national legislation, which caused considerable problems. AMZV, f. Mírová konference v Pař́ži a reparace 1918-1938, kart. 55, file no. Cb III 1, "Minoritní smlouva s čsl. rep.".

25 For details, see PETRÁŠ, 2009, 34-42.

26 OSUSKÝ, Štefan: Ochrana menšín, in: Prúdy, vol. VI, 1922, 12-13; GÜTERMANN, 27-28.

27 For example, the well-known legal historians and professors Jan Kapras and Jan Auerhan drew up a threepage proposal for the protection of minorities under international law. See: Archiv Národního muzea (Archive of the National Museum, Praha, hereinafter referred only as ANM), f. Kapras, kart. 94, no. 4792; featuring some interesting social suggestions that were not been included in the treaties.

28 ŠOLLE, Zdeněk (ed.): Vzájemná neoficiální korespondence T. G. Masaryka s Eduardem Benešem z doby pařǐžských mírových jednání (ríjen 1918 - prosinec 1919), vol. II., Praha 1994, 254, 271. 


\begin{tabular}{|c|c|c|}
\hline$\infty$ & 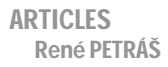 & 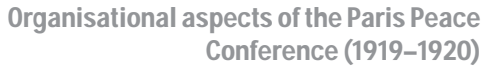 \\
\hline
\end{tabular}

ations. He was successful, for instance, regarding the right of the members of minorities to petition the League of Nations Council, because the French representative in the commission took over, and eventually pushed through, Czechoslovakia's opinion. Thanks to backstage negotiations and personal contacts, Edvard Beneš managed to influence the text of minority treaties in favour of Czechoslovakia. Apparently, such methods were quite a typical feature at the conference. ${ }^{29}$

Beside chaotic organisation, a new type of delegation was also a salient feature of the conference. In the past, conferences were predominantly attended by professional diplomats, capable of "coaching" their sovereigns or politicians. The Paris Peace Conference was officially supposed to be different in that secret diplomacy undertaken by diplomats was disavowed. In the US, in particular, public opinion was strongly emphasised. Therefore, the conference was attended by hundreds of journalists who criticised many aspects, particularly the attempts at backstage negotiations. The journalists even demanded access to, or at least daily reports from, the meetings of the Highest Council. That was openly refused by the British and French politicians, arguing that the presence of journalists would lead to demagoguery appealing to the public rather than to rational solutions. Regrettably, demagoguery abounded anyway, especially among small states whose demands were often disproportionately large. Indeed, unlike in the past when the public had hardly any information about concluded treaties, let alone about the negotiation process itself, at this conference, the importance of public opinion and the general awareness of the public were quite significant.

Likewise, criticism of the old traditions prevalent in diplomacy resulted in a different composition of delegations. Rather than professional diplomats with a legal background as in the past, the participants in the conference were economists, soldiers, or experts in various branches of social sciences. ${ }^{30}$

Hardly any negotiations about the terms of peace treaties were conducted with the defeated states. The key peace treaty with Germany was agreed upon by the Council of Four as early as on 4 May and sent for printing; two days later, the treaty was agreed upon by the plenary session. The Germans sent a large delegation to Paris, in total 180 persons, but with very limited success. The French had organised their arrival in a rather humiliating way, intentionally prolonging their journey to lead them through ravaged regions, to eventually subject them to an offensive reception on their arrival in Paris. Germany had hoped that the victorious countries would follow Wilson's Fourteen Points, and the US would subdue the (mainly) French hatred; however, the peace terms were an unpleasant surprise for the Germans. The German delegation, nonetheless, tried to draw up elaborate objections and counterproposals, and challenged in particular Article 231, which designated Germany as the blameworthy party in the war, subjecting the Germans to the duty to provide compensation for the damage. ${ }^{31}$

The victorious great powers were not particularly pleased with the peace terms either; the Americans expressed sharp criticism and the foreign minister Lansing called the peace

29 For details, see PETRÁŠ, 2009, 36-42.

30 KUKLÍK - PETRÁŠ, 62-65.

31 MACMILLAN, 448-452. 
terms harsh, humiliating, and largely impossible to fulfil. By contrast, the French considered the treaty too lenient because they had demanded the strategic border on the Rhine. The other countries concerned were in many cases considerably disappointed too, which greatly facilitated the rise of extreme right-wing and revisionist regimes in many European states. But that is a different story.

\section{Abstract}

The Paris Peace Conference (1919-1920) was expected to resolve all the numerous issues after World War I, but the organisation of this gigantic event was rather insufficient. The conference was held in Paris, recognising the important position of the principal country of the Allied victors. In the past, conferences were predominantly attended by professional diplomats, capable of "coaching" their sovereigns or politicians. The Paris Peace Conference was officially supposed to be different in that secret diplomacy undertaken by diplomats was disavowed. The criticism of the old traditions prevalent in diplomacy resulted in a different composition of delegations. Rather than professional diplomats with a legal background as in the past, the participants in the conference were economists, soldiers, or experts in various branches of social sciences.

\section{Keywords}

Paris Peace Conference (1919-1920), World War I, history of diplomacy, League of Nations, international legal protection of minorities

\section{References}

Archiv Ministerstva zahraničních věcí (AMZV)

Archive of the Foreign Ministry, Praha

f. Mírová konference v Paříži a reparace 1918-1938, f. Pařížský archiv

Archiv Národního muzea

Archive of the national Museum, Praha

f. Kapras

GÜTERMANN, Christoph: Das Minderheitenschutzverfahren des Völkerbundes, Berlin 1979.

HUDSON, Mauley O.: The Protection of Minorities and Natives in Transferred Territories, in: What Really Happened at Paris. The Story of the Peace Conference 1918-1919 by American Delegates, HOUSE, Edward M. - SEYMOUR, Charles (eds.), New York 1921, 204-230.

KLIMEK, Antonín: Jak se dělal mír roku 1919. Československo na konferenci ve Versailles, Praha 1989 (Slovo k historii, no. 19).

KUKLÍK, Jan - PETRÁŠ, René: Nadnárodní integrace v Evropě, Luzern - Praha 2007.

MACMILLAN, Margaret: Mírotvorci: Pařǐžská konference 1919, Praha 2004. 


\begin{tabular}{|c|c|c|}
\hline $\mathcal{W}$ & 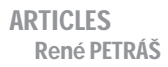 & 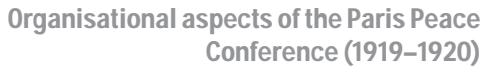 \\
\hline
\end{tabular}

MILLER, David Hunter: My Diary at the Conference of Peace, vol. XIII, New York 1924.

OSUSKÝ, Štefan: Ochrana menšín, in: Prúdy, vol. VI, 1922, 10-22.

PEŠKA, Zdeněk: Otázka národnostních menšin na Pařǐžské mírové konferenci, in: Zahraniční politika, vol. 9, 1930, 215-234.

PETRÁŠ, René: Mezinárodní ochrana menšin v teorii a praxi meziválečné Evropy, in: Zrod nové Evropy. Versailles, St.-Germain, Trianon a dotváření poválečného mírového systému, Praha 2011, 415-424.

PETRÁŠ, René: Menšiny v meziválečném Československu, Praha 2009.

PETRÁŠ, René: Meziválečné Polsko, Československo a mezinárodněprávní ochrana menšin, in: Świat, Europa, Mała ojczyzna. Studia ofiarowane Profesorowi Stanisławowi Grodziskiemu w 80-lecie urodzin, Biełsko-Biała 2009, 853-860.

ŠOLLE, Zdeněk (ed.): Vzájemná neoficiální korespondence T. G. Masaryka s Eduardem Benešem z doby pařížských mírových jednání (ríijen 1918 - prosinec 1919), vol. II., Praha 1994.

TEMPERLEY, Harold W. V. (ed.): A History of the Peace Conference of Paris, vol. V., London 1921. 